\title{
THE RIGHT TO ASYLUM IN ALBANIA AND POLICIES AGAINST ILLEGAL MIGRATION
}

\author{
Artela Roshi* \\ "Law student at Epoka University of Tirana (Albania)

\begin{abstract}
The right to asylum in Albania is part of the fundamental human rights and freedoms sanctioned in the Constitution of Albania and the domestic legislation. Starting from the dark communist period of human rights in Albania, until today, the right to asylum has evolved continuously. This article will focus on an analysis of the right to asylum in the international legal framework and particularly in Albania, taking it along its development and focusing on the current sanctioning in the legislation of this right. The paper will shed light on the development of the right to asylum in the Albanian legislation, by analysing the dimensions of this right from the international and domestic legislation. For more, the treatment of asylum seekers has become an increasingly frequent subject of treatment by the European Court of Human Rights, during the implementation of the European Convention on Human Rights. The analyses of the European Court of Human Rights will help to understand the international obligations / standards in the field of asylum in Albania. In conclusion, the article will highlight the approach of the right to asylum provided in the Albanian legislation in the framework of its approximation with the internationally recognized standards.
\end{abstract}

Keywords: Albania, Human Rights, Migration, Right to Asylum. 


\title{
E DREJTA PËR AZIL NË SHQIPËRI DHE POLITIKAT KUNDËR MIGRACIONIT TË PALIGJSHËM
}

\author{
Artela Roshi* \\ "Studente e Drejtësisë në Universitetin Epoka, Tiranë (Shqipëri)

\begin{abstract}
Abstrakt
E Drejta për azil në Shqipëri është pjesë e të drejtave thelbësore të njeriut dhe lirive të sanksionuara në Kushtetutën e Shqipërisë dhe legjislacionit vendas. Duke filluar nga periudha e errët e komunizmit në lidhje me të drejtat e njeriut në Shqipëri, deri më sot, e drejta për azil ka evoluar vazhdimisht. Ky artikull do të fokusohet në një analizë të së drejtës për azil në kuadrin ligjor ndërkombëtar dhe në vecanti në Shqipëri, duke trajtuar gjithë zhvillimin e tij dhe fokusuar në rregullimin aktual të kësaj të drejte në legjislacion. Punimi do të hedhë dritë mbi zhvillimin e të drejtës për azil në legjislacionin shqiptar duke analizaur dimensionet e kësaj të drejte nga legjislacioni ndërkombëtar dhe vendas. Për më shumë, trajtimi i azilkërkuesve është kthyer një subjekt trajtimi në rritje nga Gjykata Evropiane e të Drejtave të Njeriut, gjatë zbatimit të Konventës Europiane të të Drejtave të Njeriut. Analizat e Gjykatës

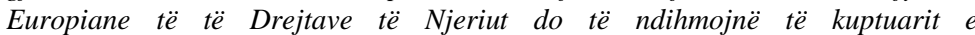
detyrimeve/standardeve ndërkombëtare në fushën e azilit në Shqipëri. Në përfundim, artikulli do të nënvizojë qasjen e të drejtës së azilit parashikuar në legjislacionin shqiptar në kuadër të përafrimit të tij me standardet e njohura ndërkombëtare.
\end{abstract}

Fjalë kyçe: Shqipëria, të drejtat e njeriut, migracioni, e drejta për azil

\section{Introduction}

Albania comes from a communist past where the dimension of human rights were treated in the light of the dictatorship of the proletariat. Article 2 of the Albanian Constitution of 1976 has stipulated the dictatorship as follows: "[t]he Socialist Popular Republic of Albania is a state of dictatorship of the proletariat and expresses and protects the interests of all workers" (1). Regarding the foreigners and their rights, Albania recognized only the right to housing foreign nationals who were persecuted by their country because of their activity for the benefit of revolution and socialism, democracy and national liberation, as well as the advancement of science and culture (2). Prior to 1990 Albania was isolated from East and West, strictly controlled all movement across its borders and did not recognize the 1951 Refugee Convention (3). In contrast, the first Constitution of the democratic regime has recognized human rights and freedoms of foreigners equally with human rights and freedoms of Albanian citizens. According to article 16 of the Albanian Constitution, the fundamental rights and freedoms and the duties contemplated in the Constitution for Albanian citizens are also valid for foreigners and stateless persons in the territory of the Republic of Albania, except for cases when the Constitution 
specifically attaches the exercise of particular rights and freedoms with Albanian citizenship (4). The sanctioning of the rights of foreigners is reinforced by the principle of prohibition of collective expulsion. On this issue, the Constitution states that the collective expulsion of foreigners is prohibited, while the expulsion of individuals is permitted under the conditions specified by law (5).

After the communist regime, a vast number of international treaties became part of Albania's domestic legislation, past of which is even the UN Convention relating to the Status of Refugees approved on 28 July 1951. Albania has ratified the Convention relating to the Status of Refugees on 18 August 1992.

\section{The International Legal Framework on the Right to Asylum}

Right to asylum is the right to seek and obtain the status of refugee. Its most important principles are non-refoulement, non-penalization and non-discrimination (6). Most comprehensively, this right was defined in the 1951 United Nations Refugee Convention as well as its 1967 Protocol, and this definition of this right is agreed by 149 countries (as of 2020) (7). Referring to the article 1, paragraph 2 of the 1967 Protocol, which removed the geographical and temporal limits of the Convention, a refugee is anyone who, owing to well-founded fears of persecution for causes of race, religion, nationality, membership of a particular social group or political opinion, is outside the country of their nationality and is unable or unwilling (because of their fear) to seek protection from that country; or, in case of a stateless persons, when one is outside their former country of residence as a result of such events or such fear and is unable or unwilling to return there. In the case of persons with more than one nationality, the term "country of nationality" means each of the countries of which they are a national, in which case that person should seek the help of both of their countries of nationality before being deemed to lack protection of their country of nationality (8). This right ceases to exist for persons such as those previously defined, when, by their own free, they will reclaim protection of their state of nationality; they have regained their lost nationality; they have gained the nationality of another State and now enjoy that State's protection; they have, by their own free will, decided to reestablish themselves in the countries which they left for fear of persecution; they, whether national or stateless persons, no longer are in the same situation that gave them the status of a refugee since the circumstances that brought to such a status have ceased to exist (9). This definition does not apply to any person that already enjoys rights and carries the obligations of the country in which they are residing (10), or to people for which there are serious reasons to consider that they have committed serious crimes such as crimes against humanity, war crimes, crimes against peace, serious non-political crimes prior to being admitted as a refugee, or have been guilty of acts contrary to the principles the United Nations follow (11).

However, the 1951 Convention is not the only definition of the right to asylum there is (which is made evident by the very first article of the Convention that acknowledges previous treaties and refugee status definitions), but it rather is the best codification of the right to asylum that we have to date. This Convention is grounded on article 14 of the Universal Declaration of Human Rights (12), which sanctions the right to seek and enjoy asylum from persecution in other countries, provided that the persecution is not a result of a serious non-political crime or act contrary to the principles of the United Nations (which as mentioned before is clearly a part of the Convention). 
For the purpose of this paper, we will be focusing our attention only on the Convention and its protocol as international pieces of legislation in which Albania is part.

\section{The Right to Asylum Stipulated in the Albanian Legislation and Policies against Illegal Migration}

Albania has been from 18 August 1992 a contracting country to both the Convention Geneva, on 28 July 1951, adhered to by decree of the President of the Republic no. 200 of 3 June 1992 - and its Protocol (New York, 31 January 1967). In addition to this, Albania has (partly) followed the Council of the European Union's (EU) Directives (13) no. 2001/55/EC, no. 2003/86/EC, no. 2011/95/EU, no. 2011/32/EU, no. 2011/33/EU in the formulation of law 10/2021 "on asylum in the Republic of Albania". Albania has signed and ratified the agreement with the UN High Commissioner for Refugees, through Law no. 7833, dated 22 June 1994, proclaimed by the Decree of the President of the Republic no. 878, with date 6 July 1994. It has also ratified the 1954 Convention for the Status of Stateless Persons and the 1961 Convention on the reduction of statelessness (14). For the aforementioned reasons, Albania is considered a juridically civilized country (15). Albania also has a long well-known history of refugee protection - such as the protection of Hebrew people from Germans during World War 2 (16), which was a statewide strategy - that predates the Convention. The customary law has always been that of welcoming those that have no protection (17) as being "guests of the household" and, in written law, it has been part of Albanian legislation since 1469 with the Statutes of Shkodra, article 1, which gives equality to both natives of the commune and foreigners (18). However, there is a lack of continuity when it comes to this right, as there is for many other rights in Albania. The communist period cut ties with all previous laws and customs and created this legal and moral vacuum that is hard to fill even today, after more than 30 years since the regime ended. Many rights that were sanctioned and sacred before ceased to exist or were greatly deformed but there is not much that needs to be said about that topic as far as it is mentioned that the right to life itself was not granted. As for asylum-seekers it is basically a pointless question because free movement was not allowed inside the country unless the State permitted it, let alone the possibility for free movement of Albanian nationals or other nationals in and out of Albanian borders without restrictions. The surveillance was so great that in every key border area there was (and they still remain) a fortified military base to capture all those who dared to try and get out of the border.

Although the 1976 Constitution in its article 65 permits foreigners that have contributed to the revolution and socialism, democracy and national liberation, as well as the advancement of science and culture, to enter the country and find asylum, this provision was pointless since Albania was part of the Communist Bloc and as such was bordered with communist countries only. There was no reason for anyone who qualified for the asylum Albania provided to seek it in Albania, because people that were "contributors to the revolution and socialism" would need to seek asylum in any country of the Communist Bloc near their own country, while Albania was not an option since it was located in the midst of communist countries which would require one to travel through a couple of communist countries before coming to Albania or going there (Albania) through a sea route, which was again an alternative among other communist countries with shorelines. 
Furthermore, the people that would actually need asylum in Albania because of it being a border state to their own - those persecuted by their own countries - were enemies to communism/socialism and as such were not welcome in the People's Socialist Republic of Albania. Article 65 of the 1976 Constitution was merely designed for situations in which fellow "comrades" of communism could find refuge from their country's law enforcing organs. Prior to the establishment of Communism throughout Europe those that adhered to communist ideas were supposedly continuously on the run because they were organizers of riots, and this specific article arose as a means to offer protection to other communists in similar situations. However, as clarified above, such protection was unnecessary in that moment of time.

One of the greatest problems of regime legislation in general is the fact that they seldom uphold their own principles and, more likely than not, they always created double standards of written law and unwritten "survival" law. However, this never went as far as becoming part of international treaties that were completely in contrast with internal legal mechanisms and so Albania did not sign the 1951 Convention despite being a country with a 482 years of refugee acceptance history at that point in time (19).

However, even with the beginning of the so-called democratic hybrid political system now in place (20) and the signing of the Convention in 1992 (21), back when Albania did not yet have a constitution but merely "constitutional principles", did not help much in creating a dignified climate for refugees. It took another 6 years for Albania to pass the first democratic law (22) on asylum and even after that law and its amendments (23), after yet another law (24) and again another one after it (25), the law on this right still only "partly" follows the EU Council's Directives, which is Albanian jargon for "we will do it our own way and pretend that is how it is done". The main argument of this paper is that this new legal order Albania finds itself in post-communism, sadly doesn't differ much from its predecessor because like back then, now as well rights are only written about and then forgotten.

As of now in the Republic of Albania there are three laws that regulate the right to asylum:

1) Law no. 10/2021 "on asylum on Republic of Albania" (26);

2) Law no. $9098 / 2003$ "on the integration and familiar unification of people that have gained asylum in the Republic of Albania";

3) Law no. 108/2013 “on foreigners" and its amendments.

The central law for this particular right is the law (which is the reason why this paper will focus on this particular law) "on asylum in the Republic of Albania", Law no. 10/2021, that defines asylum as the international protection that the Republic of Albania gives to refugees, while a refugee is defined under the article 1 of the 1951 Convention. This law has been preceded by two other laws with the same aim, specifically the 1998 and 2014 laws. The reason for that is the constant need for approximation to EU standards.

When the first law on asylum passed in parliament in post-communist Albania, the need to have a specific law that engulfed all the principles of the international treaties Albania was a part of was evident. The humanitarian crisis resulting from the conflict in Kosovo made such a law an immediate need (27). Thus, Law no. 8432/1998 was later on completed with numerous other laws and by-laws but yet the need for closer approximation was shown in EU and UNHCR reports. The 2003 Stabilization Association Agreement signed between Albania and the European Union has asylum as one of its eight priorities also. Law no. 8432/1998 was then amended in 2009 (28). 
This law, unlike its successors, lacked a definitions article before being amended in 2009, but rather only contained an article (article 2) defining asylum itself; article 3 defining an asylum-seeker; article 4 defining what a refugee meant; and article 5 defining people under temporary protection. With the amendment of 2009, the previously mentioned articles 2-5 were all repealed and were re-implemented as a single article (article 1/1), which was also enriched by article 5/1 that stipulated the right to temporary protection in massive flux times that the un-amended law lacked. Law no. 8432/1998 stipulated the non-refoulement principle (article 7) and the granting of asylum to family members of a refugee (article 6), which have been stipulated in the preceding laws as well (however to no avail due to the fact that the legislation did not provide solutions to family members located in countries that did not have diplomatic relations with Albania, or were too far from countries that had Albanian Consulates (29); while making a clear distinction between a request for asylum and an asylum application (firstly by defining each separately in article 10 and then implementing the definitions in article $1 / 1$ of the amended law). The responsible body for asylum decisions was the Office for Refugees, a unit at the Ministry of Local Government. The office was the first stage of asylum application while the National Commission for Refugees was the appellate body made up from two different NGOs: the Chamber of Albanian Lawyers and the Albanian Committee of Helsinki (30). The National Commissioner for Refugees chaired both bodies.

It is important to note that the definitions and principles of the three consecutive laws have been the same or nearly the same and close to the Convention and its Protocol, with the exception of the difference between an asylum-seeker and an asylum applicant, which has been present in Albanian legislation up until the approval and entrance into power of Law no. 10/2021. In the practical guide of the EASO and FRONTEX (that refers to Directive 2013/32/EU), however the difference does not exist (31).

Law no. 121/2014, just like its predecessor, provided different types of protections (32): the refugee status and additional protection, alongside temporal protection, which will be discussed more in depth below.

Regarding the Status of Refugee, article 4 of the Law reiterates once more the right to asylum, while article 5 lays down the causes of exemption from this right which coincide with the exemptions of the 1951 Convention. The principle of non-refoulement is materialized in article 6 . As article 7 provides, the sole organ that decides on the requests for asylum is the National Commission for Asylum and Refugees, which is led by the Commissioner for Asylum and Refugees. In Albania, the principle of non-refoulement is granted in this law (33) and so is the principle of the "third" safe country (34).

Additional protection on the other hand is defined as the protection that engulfs an individual who, although does not fulfill the criteria for being a refugee, enjoys protection to avoid being treated in an inhumane manner based on the principles of basic human rights as defined in every international treaty in which the Republic of Albania is a party to (35).

According to this piece of legislation, in order to implement the right to asylum, there are needed proper structures which will follow the procedures (regulated by specific acts independent from this law) towards implementation of this right. We can mention the following public organs which are part of the executive as well as judicial power.

1) The highest organ is the Directory of Asylum (DoA), whose director acts at the same time as Commissioner for Asylum and Refugees (36). This directory registers 
the requests for asylum, carries out the interviews with asylum seekers, collects the documents for the requests for asylum, is responsible for giving or denying asylum (first degree), follows the measures for the protection of asylum seekers and decides on the status of people that seek asylum en masse.

2) The organs of the Border Police and Migration Police that enforce nonrefoulement, takes the requests for asylum, and notifies the UNCHR or DoA in case of an asylum-seeker or refugee.

3) The UNCHR offers guidance on the requests for asylum and monitors the handling of those requests by the Albanian authorities. According to article 23 (37), every asylum-seeker has the right of communication with UNCHR.

4) The Courts that decide on the final gaining or refusal of the refugee status or additional protection in case there has been an appeal to the decision of DoA.

The request for asylum can be of any form whether written or oral to any authority, even the Border Police, which is then followed by a formal request for asylum to the competent DNR that considers each request, who are then registered to the National Register for refugees according to article 29 of this law (38). Article 32 lays out the rights of an asylum-seeker to be accommodated while waiting for the answer to their asylum request, unless (article 34, provision 6) they have the means to financially support themselves outside of the reception center, in which case they should leave the center within 30 days from their date of arrival there (39).

As expressed in the Ombudsman reports of the approximately seven-year period from 2014 to 2021, the state of the right to asylum in Albania has been still problematic. These problems were consistent enough that for years in a row the same problems and the same recommendations were given over and over again for the treatment of asylum centers in the country, both in the open Asylum Center in Babrru established in June 2003 (40) and in the Closed Center for irregular foreigners in Kareç. The lack of economic assistance was a problem in 2014 and 2015. The lack of staff, jurists, medicals, educators, supervisors, translators was a problem during the 2014-2020 timespan. The lack of clothes and sanitary products has been a more or less permanent problem throughout the years. The rights that the Albanian legislation stipulates for asylum seekers or foreign people being held in detention have not been translated in the languages that asylum seekers in Albania understand or would be expected to understand and hanged on public and visible areas in those centers.

A very pronounced problem is the lack of recreational spaces in the Kareç Closed Center for Illegal Foreigners that implies that children stuck there with their parents do not have any means of entertainment and development activities. In 2014 and 2015, there still was no agreement between the Ministry of Social Welfare and Youth for giving opportunities to asylum seekers to create working relationships in Albania, although the legislation in force and the 1951 Convention stipulated that opportunity (41). The problem with education has also been consistent since people that were placed in such institutions at that time were not given the documentation that the Albanian legislation stipulated but only a signed A4 paper from the Border and Migration Police that did not suffice to register any refugee in Albania in higher education or private education (42). Furthermore, the rules for obtaining asylum should have been published and hanged in the areas of the closed illegal foreigners in Kareç in order for the people in detention to 
know and to be able to utilize the procedures and possibilities the Albanian legislation offered to their specific situations (43).

The fact that the legislation of that time did not distinguish and offer special protection to children and vulnerable groups - which the Ombudsman defines in its reports as women, members of the LGBT community, disabled persons, children-mentioned above-and the elderly (44) - made the trafficking and exploitation of these categories of people a massive problem. Another issue of the legislation of the time (and I want to emphasize that in this particular moment it is only the legislation that is discussed and not its implementation) was the fact that UNCHR, IOM and OSCE were not given much access to the process of asylum application decisions, thus harming the transparency of the process (45). The concept of the third safe country and a safe country of origin although mentioned in Law no. 121/2014 was not deemed to be enough by legal professionals (46). Problems with lack of facilities for unaccompanied minors alongside problems with the process of pre-screening and detention remained as challenges (47) despite the FRONTEX collaboration with the Albanian Border and Migration Police in the border point at Kakavija.

For all the reasons mentioned so far, a new Law on asylum was proposed and was voted in parliament on 1 February 2021 (48). This Law, numbered 10/2021 was, as referred to the word of the Minister of Internal Affairs held in front of the Parliament and the relation that was presented in the parliamentary commissions and the Parliament itself, a significant improvement since it incorporated, partly, newer European Directives (49). The Directives the new Law was based on were nos. 2001/55/EC (which was incorporated in the previous Law as well), 2003/86/EC, 2011/95/EU (incorporated in the previous Law too), no. 2013/32/EU, 2013/33/EU.

Directives 2003/9/EC, 2003/86/EC and 2005/85/EC were no longer included in this Law although they were part of Law no. 121/2014 because of being outdated. The improvements to the law included the application of refugee-status people for Albanian citizenship through the process of naturalization (50), the meaning, reasons and actors of persecution were for the first time introduced in Albanian law (51), the separation of the responsibilities of the respective institutions dealing with asylum made clearer (52), legal vacuum concerning vulnerable groups filled (53) and the right to education guaranteed (54).

What piques one's interest in terms of differences between the old and new law was the unification of asylum request and asylum application, that I could not find expressed elsewhere, which brings this paper to its next section dealing with the dimensions of the right to asylum seekers.

\section{Dimensions of the Right to Asylum Seekers in the Albanian Legal Framework}

As has been so far elaborated, the legislation relating to the right to asylum in Albania has had multiple changes in a thirty-year period of hybrid democracy. It is my personal opinion that the reason for that more than anything else, has been the creation and adoption of law when it is too late to prevent the consequences of a crisis. At times it seems that the crisis comes more from reaction to media scandals and European Union's positive pressure following these scandals regarding the topic than actual governmental reflection on this fundamental right, as the continuous ignoring year after year of the 
recommendations of the Avokati $i$ Popullit (People's Advocate, the Albanian Ombudsman) might prove.

The first law on asylum comes in the same year as the massive flux of Kosovo Albanian (55) flew their homes and came to Albania to seek refuge, while the country had been part of the Refugee Convention for 6 years by that point in time and had not yet created a legislative framework for the principles it had promised to abide by. It is also worth mentioning that the country at that time did not only lack a law on asylum but a constitution as well and was running on a document of constitutional principles up until the year of 1998 - so the legal vacuum was more or less unavoidable.

The second law comes a few years following the outbreak of war in Syria and the beginning of the peak of the immigration crisis that expanded throughout the whole of Europe, and it fails to properly, fully integrate the EU Directives of the time in the national legislation. It coincides with the acceptance of the organization Mujahideen e Khalq (MEK) by the Albanian government, that was not very welcomed by the Albanian people themselves, which, so far as media accounts go, perceives asylum seekers and refugees as bad influence and criminal leaning people. This is particularly ironic when faced with the fact that Albania nearly topped the chart for asylum seeking in recent years (56), most of the time competing with Syrians for the first place where all were after fleeing from war. It is also ironic considering the massive exoduses of 1991 and 1997 (57) that Albanians went through and the constant complaint that people that received them in their countries treated Albanians as criminals. It seems that history gave its own dosage of irony to this small Mediterranean Country.

The third law came exactly a year after the greatest scandal of asylum seeking and refugee status that has ever found its way to media outlets in the whole history of Albanian democracy, which will be discussed in depth below.

The reason why this coincidence is mentioned in media coverage and asylum laws is that this topic is seldom talked about in Albanian society unless there is media outcry about it and even in those instances the reaction from the people is very meek and negative to the asylum seekers in question. The exception to this would be the welcoming of our ethnic brothers and sisters, the Kosovars, but so far as a human of other ethnicity and nationality is concerned there is not much solidarity by Albanians.

That above being said, it is also more or less a rule of thumb to propose and approve laws as reaction to media scandals (which, in all honesty, is among the most noble incentives for laws in Albania) or to hidden governmental agendas and the matter of asylum proves to be no different in that respect. All of this is expected since Albania is ranked as a hybrid democracy (58).

Interestingly, the process that creates the most problems, the pre-screening, is not given much attention. As has been so far mentioned throughout 1998 to the beginning of 2021, Albania had a separate definition for an asylum request and an asylum application. An asylum request was explicitly stated in the laws to be any signal verbal, written, gestural or any other form that indicated a request for asylum vis-a-vìs to the border authorities in both the 1998 Law (59) and the 2014 Law (60). The application on the other hand, was done by written form, either immediately by the asylum-seeker that would turn up to the responsible office for the application, or by the guidance of the border authority those that would request asylum would be instructed as to how to apply. EU Law of the time did not make the distinction between an asylum request and application but considered everyone to be an applicant by virtue of making a request. 
What Albanian law regarded as a request is a very reasonable mechanism to be put in a law, although the separation from application might have been unnecessary. By stating that any form of expression constituted in a request the law granted the right of people that could be under surveillance by their prosecutor or trafficker to signal the authorities of the help they needed, and it is a needed specification to make in cases when the asylumseeker is not proficient in any language the border authorities may be knowledgeable of. This provided guarantee that a person that would pass the border illegally would not be immediately prosecuted by the police, but sadly the guarantees the law provided were not regarded by the Border Authorities in Albania.

Many people have been put immediately to detention centers despite their plea for asylum because they were not in possession of any valid identification documentation (61) and after that have not been legally guided by a professional as to how they need to apply for asylum after they serve their sentence (62).

The new Law, no. 10/2021, however, in my opinion, will make the problem of prescreening worse. So far, the Border and Immigration Police has failed to distinguish who is an asylum-seeker from who is a trafficked person and those that are simply passing the border illegally so as to avoid serving rightful sentences in their own countries or for other non-justified reasons. Instead of being very attentive to pre-screening, our Police has simply put everyone without proper documentation into arrest, while instead they should be the first contact of any asylum-seeker and as such are obligated, if not by law and moral alike, to be a helping hand to those that fear for their lives and wellbeing. This has been the case under legislation that differed between a request and application. The new law does not mention an application at all but refers only to request. The problem however lies that unlike the previous laws that explicitly stated that a request of any form was valid, the new law mentions, in article 2 , that there needs to be a declaration of the intention to file an asylum request but it does not mention through what means that declaration is made and only continues to explain that the request itself is always in written form at the appropriate office (63).

In my personal view, a right that was already heavily violated while the means to guarantee it were expressively expressed cannot be improved by a law that does not mention the means through which this right is realized at all.

For this reason and others stated above, the right to asylum seekers (distinguished from the right to asylum as a whole), in the Republic of Albania right now is more restricted and less protected than it has ever been.

In thirty years of democratic regime Albania has produced a modern (as the reports of the Ombudsman, the relation of the new law and the minister's word in the parliament all state the same phrase "juridically civilized") asylum system-on paper only. Unfortunately, this new law does not give much hope in relation to correct implementation in real life situations.

Even as early as 2003, when the flux of asylum seekers and migrants was not so heavy, Albania had an "illusory protection mechanism" (64), as Ritvan Peshkepia calls it in his article, in which rights are stipulated but not implemented. More than a real protection for asylees, Albania has been (65), and remains a hot spot for smuggling of human beings. Being a poor country, it is not a desirable destination for refugees but rather has served as a transit to European Union member states for years. The disregard of human rights by the border police and the lack of attention to the housing facilities in Albania make the situation such that no illegal immigrant would want to be confronted with the Albanian 
authorities for fear of deportation or detention and in such a situation they often turn themselves to smugglers as a way of passing through Albania unnoticed and arriving to their destination. As a result of this, recent tragedies of smuggled illegal immigrants have become part of Albanian reality (66).

The only groups of people that have a refugee status in Albania, that are still situated here and have not fled the country, are Kosovar families that could not start over in Kosovo or another country and the Mujahideen e Khalq that are situated in a camp area in Manzë, that their organization has bought for them. Even for these people integration in Albanian society is hard owing to the fact of the lack of documentation, education support and financial support. It is hard to find accurate information regarding either group. For the Kosovars the reason for that is the fact that public interest is non-existent, while for the Mujahideen, conspiracy theories seem to have taken the floor instead of unbiased media and academic work.

\section{Realization of Human Rights by the Albanian State towards Asylum Seekers; The Cases of the Kosovo Albanians v. Mujahideen's v. Harun Çelik}

The war broke out on March 1998 and ended in June 1999 as a result of the NATO bombardments (67). About a million Kosovo Albanians were forced to flee from their homes and seek refuge in Albania, Montenegro, Macedonia or European Union countries where their family members could be living (68). The exodus was massive, and Kosovans crossed the border to arrive and find shelter in Morina, near Kukës, where they were welcomed. However, it is a point of interest to note that their welcoming was not a state led initiative in compliance with the legislation for the right to asylum, but rather it was mostly a voluntary initiative of Albanian people themselves, who again after opening their homes for the Jews persecuted by the Nazis, after opening the door for the Italian soldiers persecuted by German soldiers, opened their homes and hearts to their ethnic brothers. The authority of asylum of that time was the Office for Refugees (OfR) was functioning without a statute at that time (69) and the 1998 Law on asylum lacked provisions for massive flux and regulated only individual requests. The OfR responded to the situation by accepting the Kosovars as a whole group and then returning them, after the conflict ended as a whole group (70). The OfR continued to provide support for Kosovars who did not return back till its replacement with other governmental bodies. Yet the ones that provided Kosovo refugees with shelter and help were majorly civilians of the Albanian people and international partners to the Albanian people. Refugees were taken inside homes to reside there for at least two months, no questions asked. The majority of them were placed in Kukës, sheltered by civilians, some were sheltered by camps put in place by international help from NATO or the governments of foreign countries (Spain in particular, established the camp of Hamallaj, near Durrës) and yet others were taken in by homes in the whole country (71). However, although the hospitality of Albanians echoed throughout international media, it is still uncertain as to what the Albanian government actually did to help those refugees. It seems that the role of state was negligible in the grander scheme of things and only served to provide shelter to those unfortunate enough to remain in Albania.

Another instance of asylum seeking that was covered by the media was the arrival of Mujahideen e Khalq organization. After concerns for their security in their previous location in Iraq, MEK was relocated, after an agreement signed in 2013, with the help of 
the USA, to Manze, Albania (72). The camp was built with the group's own expenses (73) and they were finally settled there in 2016 (74). The information on the group is closely guarded and there are many controversial accounts on the way it operates and the rights that the group allows or denies to its members are subject to much speculation as well. Although clearly in need of a refugee status since they were and are being killed and persecuted in their country of origin (Iran) and their country of former residence (Iraq), the Mujahideen in Albania had not obtained a status of any sort up to at least 2018 (75), although by that time a part of them had been staying in Albania for 2 years. All media accounts that come from the camp raise new suspicions on the way of life people there follow. However, some facts cannot be doubted: the Mujahideen can defect from the camp and live in Albania freely.

Often, in recent years, in Albanian Television there have been interviews with detectors of the camp that now live normal lives in the streets of Albania. They are not being extracted from the country because they defected, but they lead normal private lives. This, of course, is great news for foundational human rights in Albania, but we shouldn't be so quick as to sing "Victory", yet.

In Albania, although the Law for integration of refugees has been passed since 2003, the normative acts needed to fulfill the legislation are yet to be issued. This means that in reality, some rights, such as the right to access private education, are inaccessible to refugees because they do not possess the pieces of documentation that Albanian private education requires and this not because of their own fault but because of objective reasons (such as the fact that they left their country of nationality for fear of persecution and could not possibly gather all documentation that they would need for the continual of life in another country). For the same reasons it is virtually impossible for a refugee to continue higher education in the Republic of Albania because they do not possess the pieces of documentation that verify their current level of education. This issue applies to both Kosovars and the Mujahideen people that might have such aspirations. Refugees, although article 27 of Law no. 121/2014 "on asylum in the Republic of Albania" (76) stated that they could be provided with documents for free movement, the reality is that the only "document" refugees possess (so far as updated information from the implementation of the new law is yet to be accessible), whether for identification and travel, is an A4 format paper with a seal from the border and migration police that does not contain an ID number but only a protocol number, while all identification documents in the Republic of Albania contain an ID number (77). There were, up until 2013, no documents issued by the Civil Status Office of Albania for refugees although this is a flagrant violation of the Law "on foreigners" and to top it all off although there is a Law for family unification there are no provisions for cases in which the family of the refugee are not located near or in countries that have Albanian consulates, making it practically impossible for families to be united (78).

This clearly shows that the Albanian State is not very serious in providing rights to refugees other than in form of writing. This impression will of course be heightened when the case of Harun Çelik comes to mind.

On January first, 2020, a single line of news "decorated” Albanian TV Channel interfaces: "Turkish national Harun Çelik extracted because of using false documents". That was all that was said, on that afternoon. However, as hours turned and information surfaced it turned out that the Turkish media were boasting their informative service for the capturing of "FETO terrorist" Harun Çelik in cooperation with the Albanian authorities (79). 
The controversy was understandable. News outlets of two different countries were telling different stories on the same events. One of either had to be lying and as time revealed that was Albania.

Harun Çelik had been captured at the Tirana International Airport "Nënë Tereza" in July 2019 travelling from Kazakhstan to Canada together with Selim Simsek with fake Canadian Visas. Both men had been put to trial immediately and Çelik was sentenced to 8 months of prison (shortened to 5 months and a half) which ended on January $1^{\text {st }} 2020$. The violation of law had already begun. Firstly, the Law on asylum of that time, Law no. $121 / 2014$, stated that no foreigner should be put in detention even if traveling through the border with fake documents in case they explain that they were using that document to pass the border in order to seek asylum. Even so, the fact stands that Harun Çelik had a valid Turkish Passport, which is all that is required to pass an Albanian Border. He was sentenced for a fake Canadian Visa which is not a requirement for entering the territory of Albania, therefore Harun Çelik entered the Albanian border in a legal way. The fact that he had in possession a visa for another country deemed to be fake by Albanian authorities did not make him an illegal immigrant, if anything it brings suspicion as to why Albanian authorities would flip through someone's passport to find a visa for another country and then verify its validity. The Penal Code of the Republic of Albania, article 189 , first paragraph expresses that the falsification or usage of a falsified visa is sentenced from six months to four years of prison. Fact is that Harun Çelik did not attempt to use his falsified visa and the law punishes the usage not the mere possession of such a document. Nonetheless, he was sentenced for a crime (as falsification is defined by virtue of having a maximal punishment of more than two years) and as a result was sent to serve his sentence at Prison 302 in Tirana (80) instead of being considered an illegal immigrant and being sent to the Closed Center for Illegal Foreigners in Kareç.

The day of getting out of prison, Harun was expected by a group of fellow Gulenists that were told that he would need to go to the Directorate of the Border and Migration Police to "throw a signature" (81) but Harun was in fact sent to the Turkish Embassy, who for some reason although having announced in its official page that 1 January (2020) was considered a holiday and the embassy was closed, did not hesitate to open its door to Harun Çelik, as the General Director of the Police, Ardi Veliu, later admitted to BIRN (82) that this indeed happened in order for Harun to be issued a valid document to cross borders.

Questions arise. Why would a foreigner that had passed the border in a completely legal way be deported to his country of origin so abruptly after serving their time in prison? Why would Çelik even need a new passport, when the valid one with which he has passed inside Albania was issued by Turkey in June 2011 and would expire in June 2021, while the deportation took place on the very first day of 2020 ?

As it turns out the reason was to make Harun sign the deportation act and make the case such that he did not want asylum himself.

Further questioned by BIRN on the matter, the General Director of Police, Ardi Veliu, replied that whether he shouted "asylum" or not was irrelevant since there was no formal request for asylum. In this we find two legal faults. Firstly, the law of that time, in article 3 , paragraph b) (83) defined the request for asylum as any request in any form in any time, made in front of relevant Albanian authorities, which mean that a verbal call would be enough for the request to be registered as such, while the formal request that Veliu is referring to would be called an asylum application (article 3, paragraph c)) (84). 
Reaction to remember Albania of the Convention it is a party to was immediate and the EU Delegation (85) in Albania expressed the opinion that the Republic of Albania should comply with the principles that it itself has agreed to.

Internal reaction was immediate as well. After a request for interpellation with the Internal Minister (deposited on 9 January 2020) was requested by member of Parliament Artur Roshi (86), in which Mr. Lleshaj, internal minister of Albania at that time, was asked whether there was any political Turkish influence in the taking of this decision and whether the procedure that was undertaken was deportation or extradition. The interpellation was consumed only on 3 February 2020 (87), about a month after the incident.

To questions asked the minister replied that such administrative measures were not a competence of the Ministry of Internal Affairs. However, the Penal Code of the Republic of Albania (88) specifies that if there is any reason that raises suspicions for the safety of an individual it is not allowed to extradite them out of the country and as was previously established in this paper the organs of the Police (which are dependent on the Internal Ministry) are the very organs that carry out the principle of non-refoulement. The Minister also mentioned the Border and Migration Police as the authority that was in fact the authority that carried out the extradition with the pretense of stopping an illegal migrant from migrating illegally to other countries.

The minister put an emphasis on the illegal entrance (which was not even illegal) of the individual conveniently ignoring the fact that most asylum seekers are illegal entries as article 11 of the law of the time provided, should not be prosecuted within 10 days of their entrance unless they are captured with false documents but even then they need not be prosecuted so long as they have used those documents to escape from their country and have voluntarily admitted this fact in their application for asylum. This time limit of only ten days was criticized for being too short because an asylum-seeker cannot be expected to become familiar with the legislation in place and the procedure for seeking asylum within 10 days for which reason many asylum seekers did not respect the time frame allotted (89).

In this specific case the minister claims there was no such request for asylum but video records of the moment of deportation that leaked in the very first days of January 2020 on Albanian media show a man shouting "asylum" from the inside of a police car and other men following him and shouting "Harun! Harun! Shout asylum!".

However, none of these provides real factual evidence and this might be the biggest problem of all.

Why this lack of transparency? Why cannot Albanian citizens be shown full recordings from the airport that day? Why was everything covered with a one-sentence headline in the media? Why the lack of documentation, not shown to the media, that allegedly proves Harun Çelik willfully signed the order of extradition? Why was he extradited to a third country, when he arrived in Albania after being a resident in Kazakhstan? Most importantly, why was the reaction from Turkish media such a joyous reaction if there really was no connection to Turkish politics at all?

Although the Kosovars were awaited with open arms by the Albanian people, the Mujahideen were welcomed and treated relatively well by the Albanian state, they all have a point in common with the case of Harun Çelik: international politics.

It seems that Albania only knows which rights to apply when there are foreign actors that tell it to and suddenly forgets everything when other foreign actors tell it to and then yet 
again, makes up stories to lie the previous foreign actors so as to not give way to the fact that they heard the other side that time.

\section{The Analyses of the Right to Asylum in the Case Laws of European Court of Human Rights}

Article 17, paragraph 2 of the Albanian Constitution of 1998 (still in power), integrates the principles of the European Convention of Human Rights as part of the national sources of law (90). In addition to this, in its annex (91) no. 76/2016, dated 22 July 2016, article F, paragraph 8, recognizes the European Court of Human Rights as the highest appellate court.

This is significant because in Albania case law from the European Court of Human Rights has the same value as national law. The Court, in its publication guide on case law for immigration (92), mentions that in cases such as Ilias and Ahmed v. Hungary (93), "it is the duty of the removal state to determine whether or not an asylum-seeker removed to a third country instead of the country of origin risks mistreatment". This was obviously not the case in the example that this article put forth. The Court has also ruled in cases such as De Souza Ribeiro v. France, Moustahi v. France (94), that "there is a breach of Article 13 taken in conjunction with Article 8 if the time between the ordering of a the removal and its implementation is so short to preclude any possibility for an action to be meaningfully brought before a court, still less for that court to properly examine the circumstances and legal arguments under the Convention" (95). This again was not the case in the example of Harun Çelik, who was deported within a day and was not given the chance to raise a court action.

Even though part of inner legislation by constitutional provision, the Republic of Albania has not hesitated to violate ECHR case law, just like it violates its national laws.

\section{Conclusions}

The saddest thing about Albania is that ever since 1990 and the "last day of dictatorship" juridically nothing much has changed. The law is still optional and it still bends to the will of "those above". The government still does all it can to avoid obeying the law and it still tries to lie and use law as an excuse for its hidden agendas.

Despite, the article being written in 1996, much of the reality expressed in "Human Rights in Post-Communist" Albania (96), remains in place. Fundamental human rights are not really granted in Albania and despite the passing of the years the mentality of the dictatorship era has not been erased in the way the State works.

The Republic of Albania is unable and unwilling to protect and grant the rights of its citizens and foreigners inside its borders, with anything more than ink on paper. Reports as recent as the past year (97) remind us that refugees in our camps are expected to live on less than 3 euros a day, while we aspire to become part of the European Union.

All in all, the right to asylum in Albania, is just like every other right: a forgotten one.

\section{References}

(1) Constitution of the Socialist Republic of Albania (1976), art. 2. 
(2) $I v i$, art. 65 .

(3) R. PESHKOPIA, Albania-Europe's Reluctant Gatekeeper, in Forced Migration Review, no. 23, May 2005, pp. 35-36.

(4) Constitution of the Republic of Albania, amended by Law no. 8417 of 21 October 1998, art. 16.

(5) $I v i$ art. 39.

(6) UNCHR introductory note by the UN High Commissioner for Refugees, in Convention and Protocol Relating to the Status of the Refugee, December 2010, available at www.unhcr.org/3b66c2aa10.

(7) Available at www.unhcr.org/1951-refugee-convention.html.

(8) 1967 Protocol, art. 1, para. 2; and 1951 Convention, art. 1 (a), provision 2.

(9) 1951 Convention, art. 1, let. b).

(10) $I v i$, art. 1, let. e).

(11) $I v i$, art. 1, let. f).

(12) UNCHR introductory note by the UN High Commissioner for Refugees, cit.

(13) Law no. 121/2014 of 18 September, on asylum in the Republic of Albania.

(14) Albanian Ombudsman (Avokati i Popullit), On the Role of the Ombudsman Institution Regarding Migration, Tirana, July 2016.

(15) Verbal Process, 1 Februay 2021. Minister of Internal Affairs, available at www.parlament.al/Files/Procesverbale/20210208141707Procesverbal\%20dat\%C3\%AB\%201\%20shkurt \%202021.pdf; The Relation on the Law 10/2021, available at www.parlament.al/Files/Procesverbale/20210208141707Procesverbal\%20dat\%C3\%AB\%201\%20shkurt $\% 202021 . p d f$

(16) J. WEINSTEIN, Review on 'Rescue in Albania: One Hundred Percent of Jews in Albania Rescued from Holocaust' by Harvey Sarner, in Michigan Sociological Review, Vol. 12, 1998, pp. 141-46.

(17) Cfr. S. GJEÇOV, Kanuni i Lekë Dukagjini, 1933.

(18) A. RASHA, Sistemi I Azilit Në Shqipëri Dhe Sfidat Drejt Standarteve Ndërkombëtare (Asylum System in Albania and the Challenges Towards International Standards - Master Thesis), Durrës, 2021.

(19) L. NADIN, Statutet E Shkodrës, Në Gjysmën E Parë Të Shekullit XIV Me Shtesat Deri Më 1469, Tirana, 2010.

(20) Freedom House Report on Albania, 2021, available at www.freedomhouse.org/country/albania/nations-transit/2021.

(21) Available at www.treaties.un.org/Pages/ViewDetailsII.aspx?src=TREATY\&mtdsg_no=V$2 \&$ chapter $=5 \&$ Temp $=$ mtdsg $2 \&$ clang $=\_$en.

(22) Law no. 8432/1998 of 14 December 1998, on asylum in the Republic of Albania.

(23) Law no. 8432/1998 was indeed amended in 2009.

(24) Law no. 121/2014 of 18 September 2014, on asylum in the Republic of Albania.

(25) Law no. 10/2021 of 1 February 2021, on asylum in the Republic of Albania.

(26) Ibid.

(27) R. PESHKOPIA, op. cit.

(28) E. HOXHA, Asylum Seeking in Albania, in Albania Law Journal, September 2020, pp. 1-10.

(29) A. RASHA, op. cit.

(30) R. PESHKEPIA, op. cit.

(31) EASO, FRONTEX, Practical Guide: Access to the Asylum Procedure, 2016.

(32) A. RASHA, op. cit.

(33) Law no. 121/2014, cit., art. 6.

(34) $I v i$, art. 9.

(35) Ivi, art. 3, para. (gj).

(36) A. RASHA, op. cit.

(37) Law no. 121/2014, cit.

(38) Ibid.

(39) Ibid.

(40) R. PESHKOPIA, op. cit.

(41) Law no. 121/2014, cit., art. 7; 1951 UNCHR Convention, art. 14, para. 5.

(42) A. RASHA, op. cit.

(43) Ibid.

(44) Annual Report of the Ombudsman Institution in Albania (Avokati i Popullit) years 2014, 2015, 2016, 2017.

(45) A. RASHA, op. cit. 
(46) E. HOXHA, op. cit.

(47) Ibid.

(48) Verbal process of the plenary session, available at www.parlament.al/Files/Procesverbale/20210208141707Procesverbal\%20dat\%C3\%AB\%201\%20shkurt $\% 202021$.pdf.

(49) Speech of the Minister of Internal Affairs, available at www.parlament.al/Files/Procesverbale/20210208141707Procesverbal\%20dat\%C3\%AB\%201\%20shkurt $\% 202021 . p d f$ Relation on the Law no. 10/2021, available at www.parlament.al/Files/Procesverbale/20210208141707Procesverbal\%20dat\%C3\%AB\%201\%20shkurt $\% 202021 . p d f$.

(50) ENA Staff, The New Law Brings Albania Closer to International Standards, in EuroNews Albania, 2 February 2021; Law no. 10/2021, cit., art. 69.

(51) E. HOXHA, op. cit.; The New Law Brings Albania Closer to International Standards, cit.

(52) E. HOXHA, op. cit.

(53) Ibid.

(54) Ibid.

(55) R. PESHKOPIA, op. cit.

(56) EASO, Asylum Applicants from the Western Balkans - Comparative Analysis of Trends, Push-Pull Factors and Responses, 2013, available at www.easo.europa.eu/sites/default/files/public/BZ0213708ENC.pdf.

(57) www.albania.iom.int

(58) Freedom House Report on Albania, cit.

(59) Law no. 8432/1998, cit., art. 10, para. 1; ivi, art. 1/1, para. 3.

(60) Law no. 121/2014, cit., art. 3, let. ç).

(61) R. PESHKOPIA, op. cit.; Raportet e avokatit te populli, cit.; A. RASHA, op. cit.

(62) Ombudsman Reports, cit.; A. RASHA, op. cit.

(63) Law no. 10/2021, cit., art. 2.

(64) R. PESHKOPIA, op. cit.

(65) Ibid.

(66) Staff, Transportonte klandestinë / Fuoristrada bie 100 m në humnerë në Gramsh! vdesin 2 sirianë, 7 të plagosur! Pranga shoferiti, in shqiptarja.com, 23 February 2020.

(67) Staff, Why Did the Kosovo War Start?, in The Week, 2 April 2019.

(68) M. RAY, Kosovo Conflict, in Encyclopedia Britannica.

(69) R. PESHKOPIA, op. cit.

(70) Ibid.

(71) M. DHIMA, Albania, Macedonia Opened Their Arms to Kosovo Refugees, in Agencia EFE, 22 March 2019.

(72) P. KINGSLEY, Highly Secretive Iranian Rebels Are Holed Up in Albania. They Gave Us a Tour, in New York Times, 16 February 2020.

(73) N. VITJON, 'Forgotten' Mujahedins Resurface in Albania, 2021.

(74) F. MEJDINI, Iranian Opposition Ex-Fighters 'Transferred to Albania', in BalkanInsight, 26 August 2016.

(75) Annual Report of the Albanian Ombudsman, 2017.

(76) Law no. 121/2014, cit., art. 24, para. 2.

(77) A. RASHA, op. cit.

(78) Ibid.

(79) S. GÜNCELLEME, FETÖ'cü Harun Çelik, Arnavutluk'tan Türkiye'ye getirildi, in CNN Türk, 2 January 2020.

(80) V. KARAJ, 'Azil- azil': Harun Çelik u dëbua me forcë pas një ndalese në Ambasadën turke, in Reporter.al, 9 January 2020.

(81) Ibid.

(82) Ibid.

(83) Law no.121/2014, cit.

(84) Ibid.

(85) A.E. TAYLOR, EU Reminds Albania of Human Rights Obligations regarding Deportation of Harun Çelik, in exitnews, 13 January 2020. 
(86) Request for Interpellation with the Internal Minister Sandër Lleshaj by Member of Parliament, Artur Roshi, available at www.parlament.al/Kerkese/Details/103.

(87) Available at www.youtube.com/watch?v=qvQhGzsKsJg.

(88) Law no. 7895/1995, of 27 January 1995, Penal Code of the Republic of Albania, art. 11, para. c.

(89) E. HOXHA, op. cit.

(90) Constitution of Albania (1998), available at www.pp.gov.al/web/kushtetuta_2016_1082.pdf.

(91) Ibid.

(92) ECHR, Guide on the Case Law of the European Convention of Human Rights - Immigration, December 2020, section 3, subsection A.

(93) ECHR (Grand Chamber), judgment 21 November 2019, application no. 47287/15, Ilias and Ahmed v. Hungary.

(94) ECHR (Grand Chamber), judgment 13 December 2012, application no. 22689/07, De Souza Ribeiro v. France; ECHR (Fifth Section), judgment 25 June 2020, application no. 9347/14, Moustahi v. France.

(95) ECHR, Guide on the Case Law of the European Convention of Human Rights - Immigration, cit.

(96) F. ABRAHAMS, Human Rights in Post-Communist Albania. Human Rights Watch, 1996.

(97) Staff, Albania Should End Refugees' Suffering of Hunger and Violence, in reliefweb, 10 May 2020. 